\title{
СОДЕРЖАНИЕ
}

М.А Степанов, К.Р. Джабраилова, Г.И. Рыбак, Мих.А. Степанов

Влияние вертикальной опрессовки грунта однослойного и двухслойного оснований на несущую способность свай

М.Н. Шутова, С.И. Евтушенко, Д.А. Калафратов

Анализ эфффективности применения конструкций двухслойных фундаментов портала ЛЭП

на основе численного эксперимента.

Д.А. Семенов, В.И. Клевеко

Планирование модельных экспериментов по исследованию работы оснований, армированных геосинтетическими оболочками.

В.В. Антипов, В.Г. Офррихтер

Оперативная оценка напластования и удельного веса грунтов волновым методом

Т.П. Кашарина, Д.В. Кашарин

Использование оболочечных конструкций в экстремальных зонах России

\section{А.В. Бояринцев}

Репрезентативный анализ опыта строительства фундаментов на многолетнемерзлых грунтах

А.И. Полищук, А.С. Межаков

Оценка влияния наклона разделительного ряда из свай между фундаментами соседних зданий на их осадки.

Т.Н. Романова

Современное состояние вопроса газификации природным газом

Т.Н. Белоглазова, Е.С. Дубровская

Внедрение технических проектов в инженерной инфраструктуре города

А.П. Свинцов, С.Л. Шамбина, Р.С. Федюк

Влияние маслянистых жидкостей на дефоормативные свойства бетона

В.И. Логанина, Е.Б. Мажитов

Стойкость покрытий на основе золь-силикатной краски

Д.А. Скоробогатченко, Г.Д. Засорина

Технико-экономическое обоснование строительства автомобильных дорог с низкой интенсивностью движения на основании из переуплотненного грунта

\section{Г.И. Зубарева, И.В. Соргутов}

Уникальный купольный дом 